\title{
せん断曲げを受ける H 形鋼梁の崩壊形式と塑性変形能力に関寸る研究 A STUDY ON COLLAPSE MODE AND PLASTIC DEFORMATION CAPACITY OF H-SHAPED STEEL BEAMS UNDER SHEAR BENDING
}

\author{
鈴木 敏 郎*, 五十嵐 規矩夫**, 常 木 康 弘*** \\ Toshiro SUZUKI, Kikuo IKARASHI and Yasuhiro TSUNEKI
}

\begin{abstract}
In a recent study, it was clear that the beam with large web slenderness has enough plastic deformation capacity for seismic design. But the large deformation behavior and the collapse mechanism of these beams have not been cleared. In this study, the collapse mode and that deciding the maximum load are investigated by experiment study and numerical analysis. As a results, it is clear that the ratio of the shear strength to bending strength of the beam is very important factor for the plastic deformation behavior. And the plastic deformation capacity of the beam is estimated by using the ratio.
\end{abstract}

Keywords : beam, local buckling, plastic deformation capacity, ultimate strength, shear strength, collapse mode 梁, 局部座屈, 塑性変形能力, 最大耐力, せん断耐力, 崩壊形式

\section{$\S 1$. 序}

著者らは，これまでの一連の研究 1)，2）においてウエブ幅厚比 が大きな梁に対しても，フランジ幅厚比を小さくすることで耐震設 計梁として使用されるための塑性変形能力を十分有していることを 明らかにしてきた。また文献 2）ではウエブ幅厚比が大きい梁の特 徵として, フランジ幅厚比を小さくした場合に, 必ずしも塑性変形 能力が大きくなるものではないことを指摘している。これは，梁の 崩壊形式が, 構成板要素の幅厚比により変化することによるもので あることを示した上で, 塑性変形能力が最大となる構成板要素の幅 厚比の值の概略を示している。さらにこの值はせん断スパン比に よっても変化することを明らかにしている。しかし，その中では梁 の崩壊形式を規定する主要因について明確にはふれないまま, 塑性 変形能力が最大となる境界の存在のみを示している。

つまり現行では，ウエブ幅厚比が大きな梁においても，塑性設計 梁としての可能性と適用範囲の概略については示されてはいるもの の, 梁の崩壊を決定づける最大耐力決定要因については未だ十分に 明らかにされていないといえる。したがって現在では建築物の多様 化の中で，軽量化及びコストなどの面を考えれば，できる限りウエ ブ板厚を薄くしたいと言う設計者の立場からの要求は高まっている ものの, ウエブ幅厚比の大きな梁の崩壊形式並びに塑性変形能力が どのような要因で決定されているかがいまだ不明であることから，

このような梁の積極的な使用にはいたっていないのが現状である jo

このような背景の中で文献 3 ），4）では文献 5 ）で提案されてい る応力度比を参考として, 曲げ応力度とせん断応力度の比に着目し,
ウエブ幅厚比の大きな梁の塑性変形能力評価を試みている。そこで 提案されている応力度比を用いることで, ウエブ幅厚比の大きな梁 の塑性変形能力は概ね整理できることが示されている。しかし，こ の応力度比を求める際の局部座屈長さ等の捕らえ方が必ずしも明確 なものとはいいがたいなど，その評価方法はかなり煩雑なものと なっている。また, 必ずしも梁の崩壊の実体を捕らえた評価法になっ ているとは言いがたい。

ウエブ幅厚比が大きな梁あるいはウエブ板厚の薄い梁は，フラン ジ断面積に対するウエブ断面積の割合が小さくなる傾向にある。ま た比較的梁せいが高くなるため，せん断スパン比も小さくなる傾向 にある。これらの要因により, ウエブ幅厚比の大きな梁は，断面内 に生じる応力が曲げ応力よりもせん断応力が支配的になる場合が多 くなる。また，このような梁ではフランジ局部座屈が支配的な構成 板要素の連成座屈は発生しにくく, ウエブの耐力によって梁の塑性 変形性状が決定づけられると考えられる。

そこで本研究では載荷実験を通し，以上のよjなウエブ幅厚比の 大きな梁の特徵を再度確認する。その上でウエブ幅厚比が大きな梁 の崩壊形式並びに最大耐力を決定する要因に対して考察を加える。 さらに,そこから導かれる評価因子を用いて塑性変形能力を整理し， 塑性変形能力最大点との関係を明確にする。

\section{§2. せん断曲げを受ける H 形鋼梁の大变形挙動}

\section{1 試験体及び実験概要}

本実験では, ウエブ幅厚比が大きな梁の崩壊決定要因を考察する ことを目的とする。そのため構成板要素の幅厚比のみを実験変数と

\footnotetext{
* (侏構造材料研究会 代表. 工博

** 東京工業大学大学院理工学研究科建築学尃攻 助教授・博士 (工学)

*** (侏)日建設計・東京
}

Kouzouzairyou Kenkyukai Co., Ltd, Representative, Dr. Eng.

Assoc. Prof., Dept. of Architecture and Building Engineering, Graduate School of Science and Engineering, Tokyo Institute of Technology, Dr. Eng.

Nikken Sekkei, Ltd. 
せず，崩壊性状に影響をおよぼすであろう構成板要素の断面積比及 びせん断スパン比などを実験変数とした載荷実験を行った。

本研究ではウエブ幅厚比75.0，66.7を中心にして試験体を選定し た。これらはウエブせいのとり方が異なるが, 鋼構造設計規準6)にお ける制限値をみたさないものである。また一体のみ制限值をみたす ものについても実験を行った。フランジに関しては，十分塑性化後 に座屈する幅厚比のものを選定している。これらの幅厚比のものは， 文献 2 ）に扔いて全塑性モーメントを確保することが保証されてい るものである。

また板幅と板厚を変化させることで，構成板要素の幅厚比が同じ 場合には板の断面積が変化する。この断面積の変化が梁の塑性変形 性状におよばす影響を考察するための試験体も用意した。すなわち これらの試験体は，ウエブに対するフランジの断面積比を実験変数 とする試験体である。また構成板要素の幅厚比を等しくして，せん 断スパン比を変化させた試験体も用意した。これらの試験体の試験 体名，試験体形状を表 1 に示す。ただしこれらの值は公称值を用い て算出したものである。

載荷形式は図 1 に示すような単調載荷とし，両端単純支持の梁の 中央に集中荷重を載荷するものである。梁の崩壊が片側スパンで起 こるように，片側を載荷梁とするためカバープレートを用いて補強 している。また試験体側の片持梁としての変位及び荷重を計測する ために図中に示す式を用いて補正をおこなっている。

試験体に使用した鋼材の機械的性質を表 2 に示すが，試験体ごと に使用した鋼材が異なるため試験体と鋼材の対応も示している。本 実験で使用した鋼材には，明確な降伏棚が存在した。また，表に示 す降伏応力度は下降伏点の值を示している。

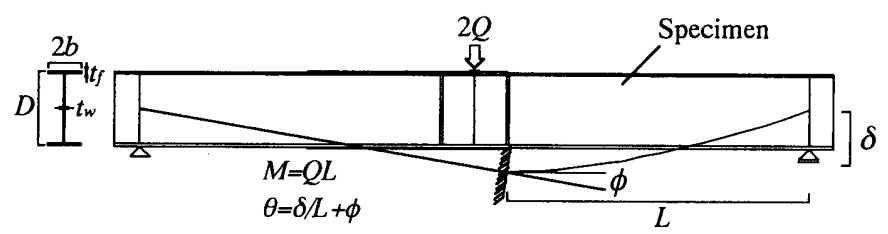

図 1 試験体図

表 1 試験体一覧

\begin{tabular}{|c|c|c|c|c|c|}
\hline Specimen & Section & $L$ & $D / t w$ & $b / t f$ & $L / D$ \\
\hline A1 & $\mathrm{H}-450 \times 200 \times 6 \times 12$ & 1800 & 75.0 & 8.33 & 4.00 \\
\hline A2 & $\mathrm{H}-450 \times 200 \times 6 \times 16$ & 1800 & 75.0 & 6.25 & 4.00 \\
\hline A3 & $\mathrm{H}-450 \times 200 \times 6 \times 19$ & 1800 & 75.0 & 5.26 & 4.00 \\
\hline A4 & $\mathrm{H}-450 \times 200 \times 9 \times 16$ & 1800 & 50.0 & 6.25 & 4.00 \\
\hline A5 & $\mathrm{H}-450 \times 150 \times 6 \times 12$ & 1800 & 75.0 & 6.25 & 4.00 \\
\hline A6 & H- $450 \times 200 \times 6 \times 16$ & 2500 & 75.0 & 6.25 & 5.56 \\
\hline A7 & H- $450 \times 150 \times 6 \times 12$ & 1100 & 75.0 & 6.25 & 2.44 \\
\hline B1 & $\mathrm{H}-400 \times 150 \times 6 \times 16$ & 1600 & 66.7 & 4.69 & 4.00 \\
\hline B2 & $\mathrm{H}-400 \times 200 \times 6 \times 16$ & 1600 & 66.7 & 6.25 & 4.00 \\
\hline B3 & $\mathrm{H}-400 \times 150 \times 6 \times 22$ & 1600 & 66.7 & 3.41 & 4.00 \\
\hline B4 & H- $400 \times 200 \times 6 \times 12$ & 1200 & 66.7 & 8.33 & 3.00 \\
\hline B5 & $\mathrm{H}-400 \times 200 \times 6 \times 16$ & 1200 & 66.7 & 6.25 & 3.00 \\
\hline
\end{tabular}

\section{2 構成板要素の幅厚比が梁の荷重変位関係に与える影響}

まずここでは，構成板要素の幅厚比がウエブ幅厚比の大きな梁の 塑性変形性状に与える影響について確認する。図 2 にウエブ幅厚比 及びせん断スパン比を一定とし，フランジ幅厚比を変化させた場合 の無次元化荷重変位関係を示寸。縦軸の荷重は部材端モーメントを 全塑性モーメントで，横軸の変位は部材角を全塑性モーメントに対 する弾性部材角でそれぞれ無次元化して示している。ただし全塑性 モーメントはフランジとウエブのそれぞれの降伏応力度を用いて算 出している。また四中の㵊大耐力点を示している。これらの表 現は以降の困においても同様である。

このフランジ幅厚比を変化させた三体の試験体を比較した場合, フランジ幅厚比を小さくすれば必ず塑性変形能力が大きくなるもの ではないことが確認できる。A2と A3では，フランジ幅厚比が $\mathrm{A} 3$ の 方が小さいにもかかわらず，塑性変形能力は逆に小さくなる傾向に ある。このような傾向は文献 2 ）のなかでもとらえており，崩壊形 式が変化することによるものであることを示している。またフラン ジ幅厚比が小さい試験体は, 他の試験体と比較して最大耐力後の耐 力少化が若干激しいものとなっている。このようにフランジ幅厚比 を小さくした場合には，その性状が幅厚比が大きい場合の性状と類 似したものではなく，全く別の性状を示すようになる。事実，後に 示す最終崩壊形状は異なるものであった。したがって，このように 別な性状を単に幅厚比のみで説明するのは困難であり，幅厚比とは 別の要因で説明，整理するのが妥当であると考える。

さらに, 図 3 にはせん断スパン比及びフランジ幅厚比を一定とし たままウエブ幅厚比を変化させた場合の荷重変位関係を示す。この 場合も図 2 と同じく，必ずしもウエブ幅厚比が小さい試験体ほど塑 性変形能力，耐力上昇率ともに高くなるというものではないことが 確認できる。この三体の中では，ウエブ幅厚比が75.0のものと 66.7 のものではほとんど同様な性状を示しており, ウエブ幅厚比の違い による大きな差異はみられない。

このようにウエブ幅厚比が大きな梁の塑性変形性状は, 構成板要 素の幅厚比のみでは明確に分離，整理することが難しいことが分か る。つまりこのような梁の塑性変形性状及び崩壊形式に影響を与え るものとして，幅厚比以外に何らかの要因が存在することを示唆す るものである。梁の崩壊性状を見極めるために以下において，単に 最終崩壊形状に着目するのみでなく，塑性変形に伴うウエブ内のU ずみ度の進展状況に着目し, ウエブ幅厚比の大きな梁の崩壊過程に 対して考察を加える。

表 2 鋼材の機械的性質

\begin{tabular}{|c|c|c|c|c|c|c|c|c|}
\hline $\begin{array}{l}\text { 圾験体 } \\
\text { 種別 }\end{array}$ & 鎆種 & $\begin{array}{l}t(\mathrm{~mm}) \\
\text { 板厚 }\end{array}$ & $\begin{array}{c}\alpha_{1}\left(\mathrm{~N} / \mathrm{mm}^{2}\right) \\
\text { 降伏応力度 }\end{array}$ & $\begin{array}{c}\sigma_{u}\left(\mathrm{~N} / \mathrm{mm}^{2}\right) \\
\text { 引張強度 }\end{array}$ & $\begin{array}{c}E\left(\mathrm{kN} / \mathrm{mm}^{2}\right) \\
\text { ヤング率 }\end{array}$ & $\begin{array}{c}\varepsilon_{u}(\%) \\
\text { 一様伸び }\end{array}$ & $\begin{array}{c}\text { Elong (\%) } \\
\text { 伸び }\end{array}$ & $\begin{array}{l}Y . R(\%) \\
\text { 降伏比 }\end{array}$ \\
\hline \multirow{5}{*}{ A } & \multirow{5}{*}{ SN490B } & 6 & 415 & 559 & 210 & 16.0 & 25.7 & 74.2 \\
\hline & & 9 & 383 & 543 & 210 & 17.0 & 25.4 & 70.5 \\
\hline & & 12 & 368 & 536 & 206 & 19.0 & 27.4 & 68.6 \\
\hline & & 16 & 377 & 541 & 204 & 19.9 & 29.3 & 69.6 \\
\hline & & 19 & 375 & 543 & 204 & 18.7 & 29.8 & 69.1 \\
\hline \multirow{4}{*}{ B } & \multirow{4}{*}{ SN $490 \mathrm{~B}$} & 6 & 398 & 552 & 196 & 20.8 & 26.2 & 72.2 \\
\hline & & 12 & 382 & 528 & 197 & 17.3 & 27.5 & 72.4 \\
\hline & & 16 & 376 & 532 & 206 & 15.4 & 29.8 & 70.7 \\
\hline & & 22 & 357 & 521 & 197 & 18.6 & 29.2 & 68.4 \\
\hline
\end{tabular}




\section{3 断面形状の違いが梁の崩壊性状に与える影響}

図 4 は，フランジ幅厚比を変化させた場合の梁の崩壊の様子を各 試験体ごとに示したものである。フランジ局部座屈の進展とウェブ せん断Uずみの進展を荷重変位関係とともに示している。フランジ 局部座屈Uずみは, 端部から $100 \mathrm{~mm}$ の位置でのひずみ 1 と, $225 \mathrm{~mm}$ の位置でのひずみ 2 の 2 箇所示している。フランジの局部座屈ひず みは，図 4 (a)中に示す位置に貼付したウエブ接合線上のUずみゲー ジの值とフランジ自由縁のひずみゲージの值の差である。通常は均 等な両者のUずみ進展が，ねじれを伴うフランジ局部座屈により乱 れが生じるため, 両者の値の差がフランジ局部座屈の進展状況を便 宜的に示すものとなっている。しかしこのひずみ度の値に物理的な 意味はなく，大小比較のみが可能なものである。またせん断ひずみ は，図中に示した三軸ゲージからウエブ上の最大せん断Uずみ度の 值を算出し，その進展状況を変位の進展とともに示したものである。 これらの試験体のウエブに使用した鋼材のせん断降伏ひずみ度は, 約 $0.3 \%$ である。また罒は, (a)に示すものがフランジ幅厚比が一番大 きいもの, (c)に示すものがフランジ幅厚比が一番小さいものであり， (b)のものがその中間的なものである。ここではこの順番に説明を加 之, 幅厚比の違いと崩壊性状について考察を加える。

これらの図をみる限りにおいて，(a)に示寸 A1はフランジ局部座 屈の進展が顕著であり, 荷重変位関係が最大耐力点に到達した時の

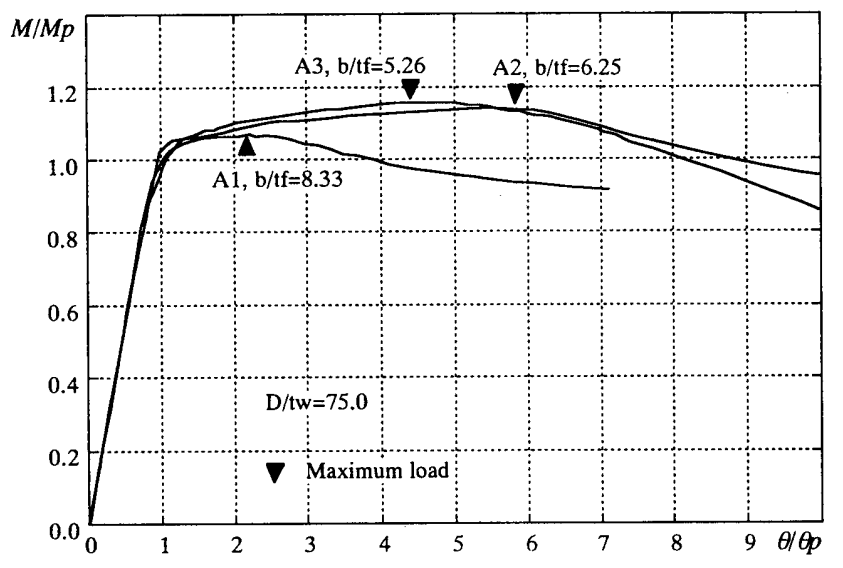

図 2 荷重変位関係に及ぼすフランジ幅厚比の影響

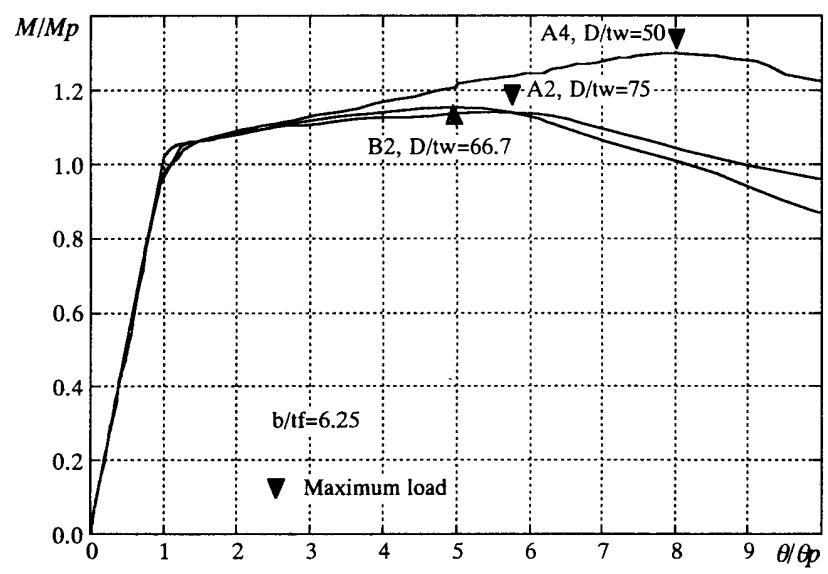

図 3 荷重変位関係に及ぼすウエブ幅厚比の影響
フランジ局部座屈ひずみはかなり大きくなっている。これよりこの 試験体の崩壊がフランジ局部座屈が支配的なものであったことがわ かる。この試験体では最大耐力時においてもウエブの最大せん断ひ ずみ度はせん断降伏Uずみ度に達しておらず，このUずみゲージ貼 付位置におけるウエブはせん断降伏していないとみることができ る。

一方(c)に示す A3は, フランジ局部座屈の進展が顕著には現れて おらず，最大耐力時のフランジ局部座屈ひずみは A1に比べて大き くなっていない。しかしせん断ひずみは, 最大耐力点を過ぎたあた クから大きく進行し始めている。逆にいえば，せん断Uずみの值が

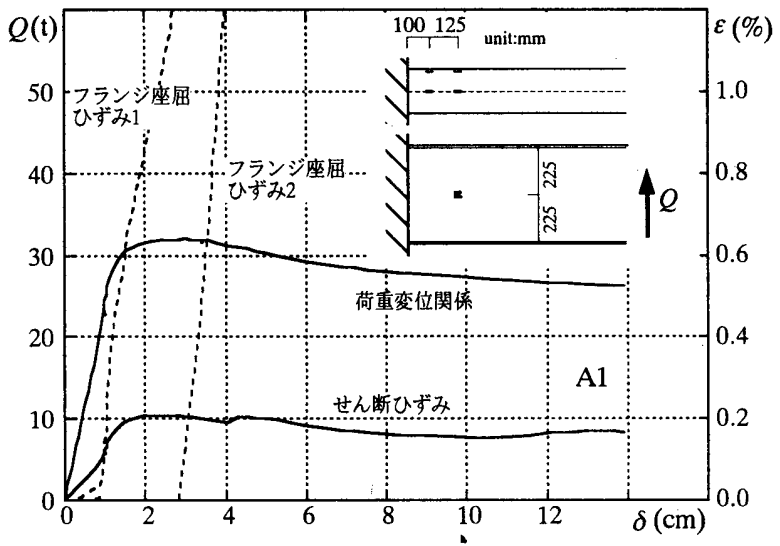

(a) A1

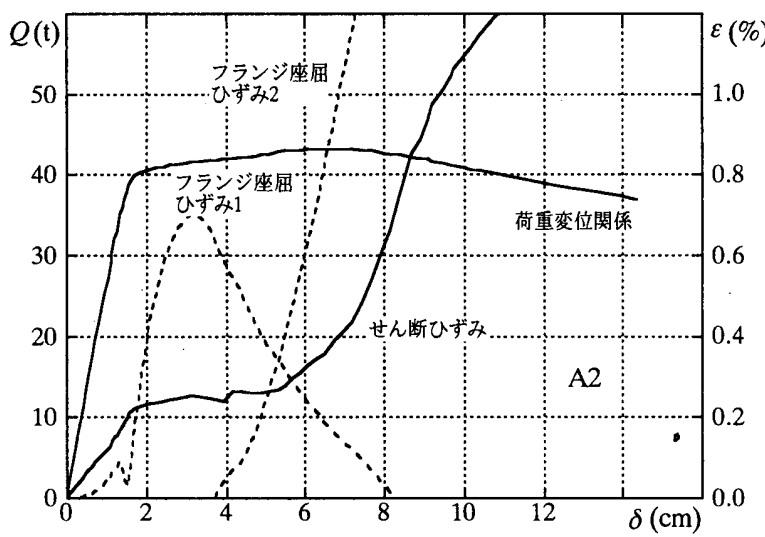

(b) $\mathrm{A} 2$

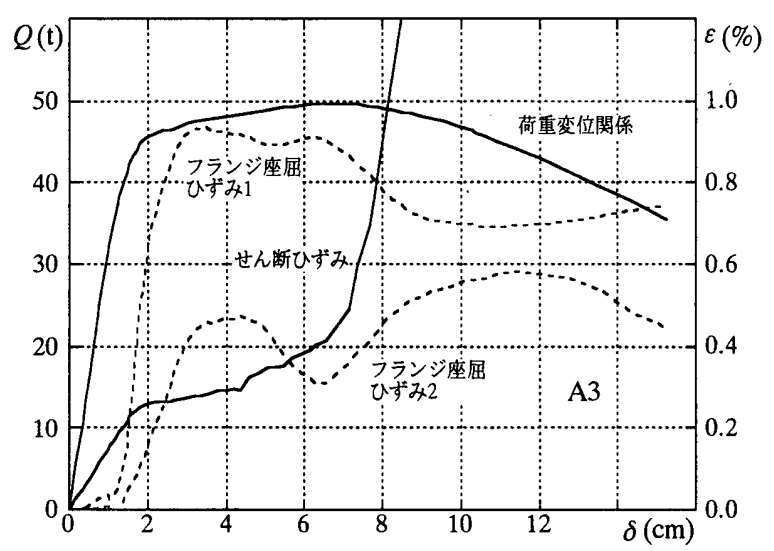

(c) $\mathrm{A} 3$

图 4 ・フランジ座屈Uずみ及びウエブ内せん断Uずみ進展状況 


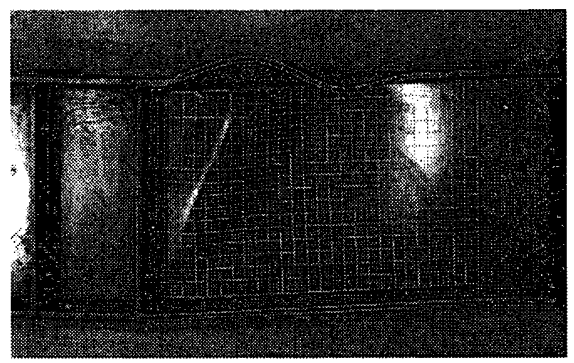

(a) A1

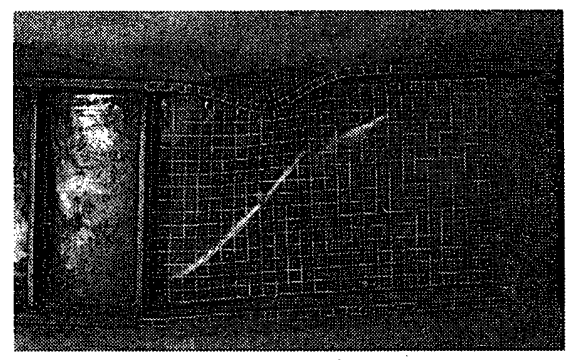

(b) A2

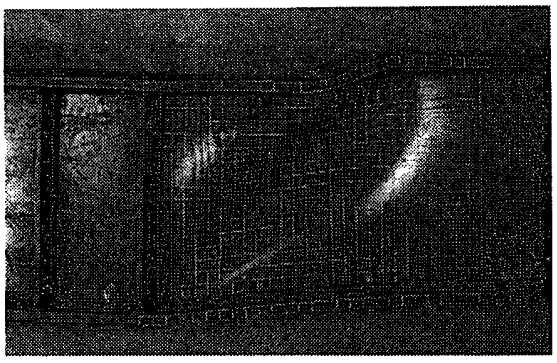

(c) A3

図 5 最終崩壊形状

降伏ひずみ度に達することで, 梁は最大耐力になっている。このよ うな状況から, 最大耐力時点においては, ウエブは端部からある位 置までの全領域において完全な塑性化状態にあると判断できる。し たがってウエブは剛性がほとんど無い状態にあり，最大耐力後の劣 化が他の二試験体に比較して急激なものとなっていると考えられ る。

また(b)に示す $\mathrm{A} 2$ はこれら $\mathrm{A} 1$ と $\mathrm{A} 3$ の性状のちょうど中間的なも のとなっている。したがって $\mathrm{A} 2$ は, フランジ局部座屈波形が成長し ながらも，最終的にはウエブがせん断降伏し，このフランジ局部座 屈によるフランジの剛性低下に伴う耐力低下とウエブせん断降伏に 伴う耐力低下がほぼ同時に発生し，梁の性状を決定しているものと 考えることができる。

これら三体の最終崩壊形状を図 5 に示す。(c)に示す A3の崩壊形 式は明らかに他の二体と異なり，ウエブの剛性低下に伴うせん断変 形が顕著に現れ，フランジにはねじれ変形が見られず，ウエブ側に 落ち込んでいる。これからも，A3はせん断力によりウエブが降伏し， 剛性が低下したことが確認できる。しかしそのせん断波形が確認で きる範囲は，端部から梁せい程度までの長さであり，せん断局部座 屈波形は梁全長に及んでいない。このせん断波形が確認できる範囲 は,フランジの塑性化領域長さにおさまっていることを確認している。

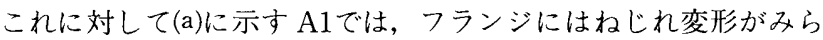
れ，フランジ局部座屈が顕著にあらわれた形で崩壊している。ウエ ブにも面外変形が確認されるものの，この変形はフランジ局部座屈 に伴う連成局部座屈的なものであると思われる。また(b)に示す $\mathrm{A} 2$ もねじれを伴うフランジ局部座屈が発生しており，A1のものとさほ ど違わない崩壊形式となっている。しかしウエブ局部座屈波形は， $\mathrm{A} 1$ ものより材長方向に長くなっており, ウエブ座屈波形の形状も いくぶんA3のものに類似している。

以上より，ウエブ幅厚比の大きな梁では，フランジ幅厚比が大き い場合にはフランジ局部座屈耐力が支配的となり，梁の最大耐力が 決定されている。しかしフランジ幅厚比が小さくなりフランジ局部 座屈が発生しにくい断面では，ウエブのせん断降伏により梁の最大 耐力が決定される。ここで梁せい，梁幅を同じにしてフランジ板厚 を増すことでフランジ局部座屈耐力を向上させた場合には，ウエブ 降伏荷重が等しいままとなる。これが図 2 でみた荷重変位関係のよ うにフランジ幅厚比を小さくすることで塑性変形能力が頭打ちにな るばかりでなく，逆に塑性変形能力が低下する現象があらわれる要 因である。

\section{§3．せん断曲げを受ける H 形鋼梁の最大耐力決定要因 \\ 3.1 梁の荷重変位関係に影響を及ぼす要因}

前章までの考察により, ウエブ幅厚比の大きな梁の最大耐力には, ウエブのせん断降伏が何らかの影響を及ぼしていることが推察され た。しかしせん断曲げを受ける梁を対象する場合，ウエブのせん断 降伏耐力は，梁の曲げ耐力との相対的な関係でとらえるべきである と考之る。構成板要素の幅厚比が等しい場合には，梁のせん断降伏 耐力に影響を及ぼす主要因としては，せん断スパン比と構成板要素 の断面積の比率が考えられる。そこで，ここではせん断スパン比と 構成板要素の断面積比を変化させた場合の実験結果を比較し，それ らが梁の荷重変位関係におよぼす影響について考察する。

図 6 は, ウエブ偪厚比 75.0 , フランジ幅厚比 6.25 と一定として, 材長を変化させた場合と，フランジ幅及び板厚を変化させてフラン ジ断面積に封するウエブ断面積の割合を変化させた場合の荷重変位 関係である。A2と A6が断面積が等しくせん断スパン比が異なるも の，A5と A7が断面積比が等しくせん断スパン比が異なるもの，A2 とA5がせん断スパン比が等しく断面積比が異なるものである。

この 4 体の荷重変位関係の全体的な傾向としてはさほど違わない ものと判断可能であるが, 本研究では, 梁の性状をとらえる上での 一つの指標として最大耐力時の変位量を考えることから，ここでも 特に最大耐力時の変位量のみに着目する。その場合, この図に示す ように構成板要素の幅厚比が等しいものでも，せん断スパン比や断 面積比が異なることで塑性変形能力に変化が現れる。この四体の試

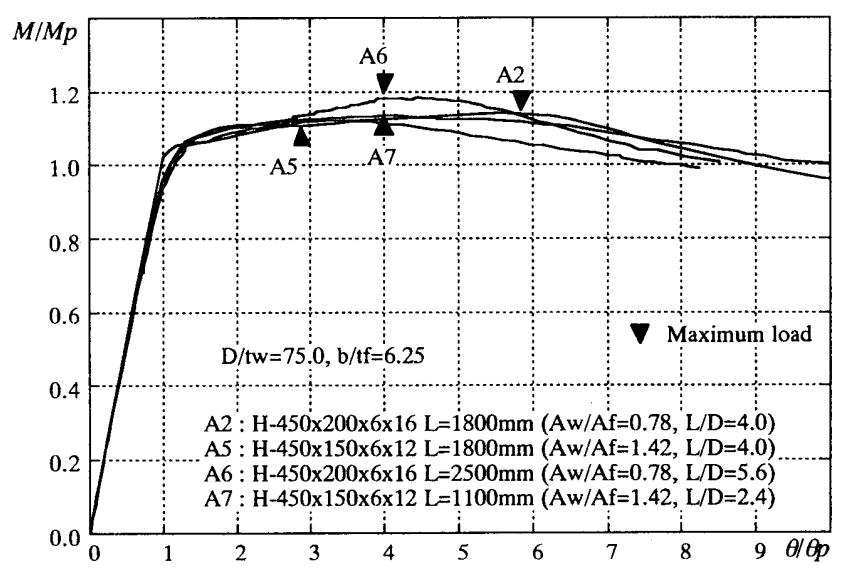

図 6 荷重変位関係に及ぼすせん断スパン比及び断面積比の影響 


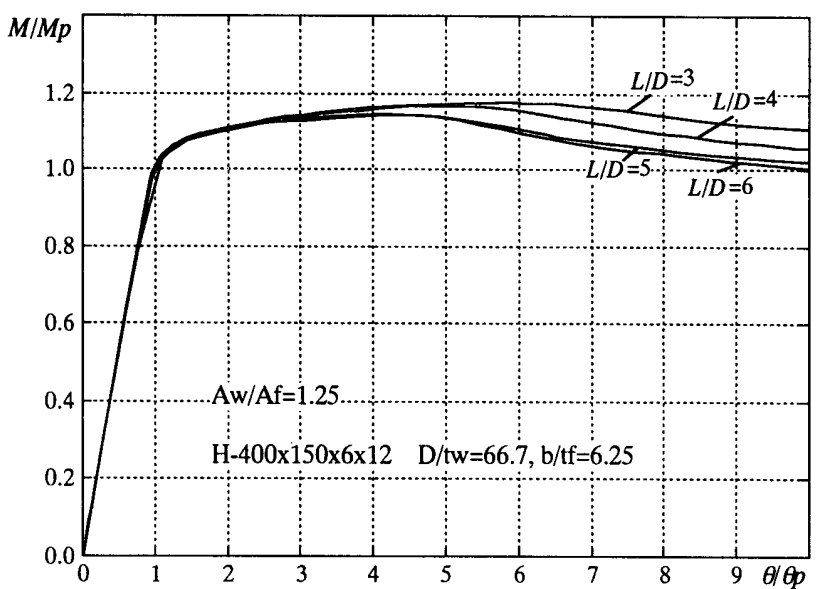

(a) $\mathrm{Aw} / \mathrm{Af}=1.25$ の場合

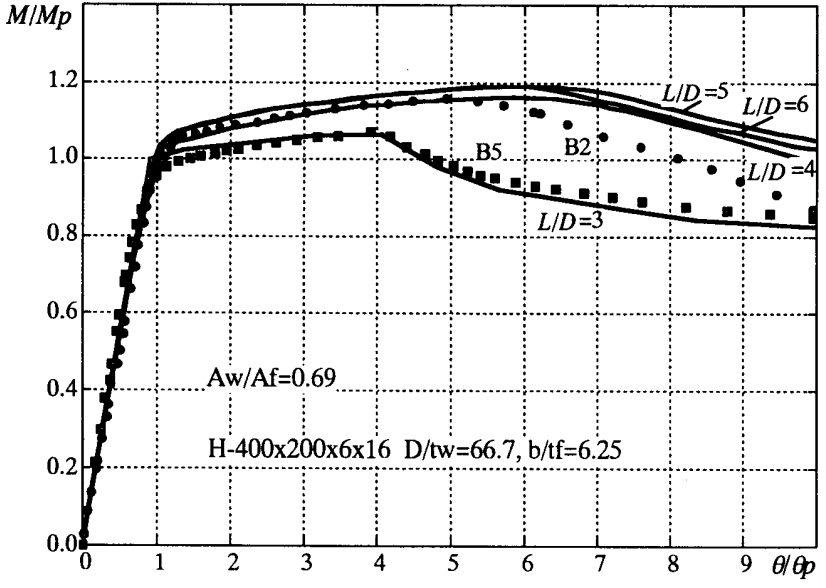

(b) $\mathrm{Aw} / \mathrm{Af}=0.69$ の場合

図7せん断スパン比が荷重変位関係に与える影響

験体で比較した場合，断面積比が大きな A5と A7を比較すると，せ ん断スパン比が小さい $\mathrm{A} 7$ の方が最大耐力時変位量が大きい。これ に対して, 断面積比が小さい A2, A6では, せん断スパン比が小さい A2の方が最大耐力時変位量が大きくなっている。また，同じせん断 スパン比の A2と A5では, 断面積比が大きい A5の方が最大耐力時 変位量が小さくなっている。つまり断面積比の違いによってもせん 断スパン比が塑性変形能力に与之る影響が異なることとなる。この ようにウエブ幅厚比の大きな梁では, 断面積比, せん断スパン比が 相互に関連しながら塑性変形性状が決定される。さらにこの断面積 比の違いとせん断スパン比の影響を次節において検討対象を増やし 考察する。

\section{2 梁が有するせん断耐力が荷重变位関係に与える影響}

断面積比及びせん断スパンを変化させた場合の荷重変位関係にみ られる違いを把握するために，載荷実験での試験体本数を増やす意 味で有限要素法を用いた数值実験を行った。解析には沉用有限要素 解析プログラムABAQUS を用いた。使用した要素は四節点シェル 要素である。材料定数は引張試験結果から得られた一様伸びまでの 部分を真応力一真Uずみの関係に変換し，その塑性部分を多直線近 似で入力している。また弾性部分におけるヤング率は $2,100 \mathrm{t} / \mathrm{cm}^{2}$ と

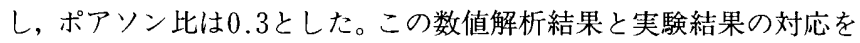
一部図 7 (b)に示しているが，概方良い对応をしている。

図 7 (a)には, 断面形状 H- $400 \times 150 \times 6 \times 12$ のものでせん断スパン 比を変化させたものを，図 7 (b)には，断面形状 H- $400 \times 200 \times 6 \times 16$ のものでせん断スパンを変化させたものを示している。ただし，こ れらは全てウエブ幅厚比 66.7 , フランジ幅厚比6.25で等しい。図中 にはフランジ断面積に对するウエブ断面積の比をそれぞれ示してい る。図 7 (a)に示寸断面積比1.25の場合の荷重変位関係ではせん断ス パン比が大きくなるに従い最大耐力時変位量は小さくなるもののそ の増加はわずかであり，ほとんど同椂な荷重変位関係となっている。 これに対して, 図 7 (b)に示す断面積比 $0.69 の$ 場合のものは, せん断 スパン比が大きくなるに従いその最大耐力時変位量は大きくなる傾 向にある。またその荷重変位関係の形状も大きく異なったものと なっている。このように断面積比によってせん断スパン比が変化す ることによる荷重変位関係の違いが生じる。

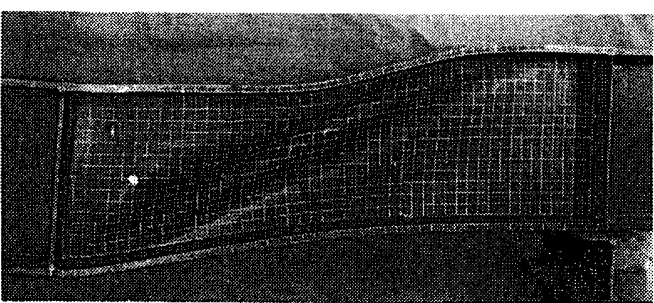

図 8 B5の最終崩壊形

また図 7 (a)の最終変形状態は全てのせん断スパン比でほぼ同様な 変形状態であった。この恋形は, 図 $5(\mathrm{a}) に$ 示すようなフランジ局部 座屈変形が顕著に発生しているものであった。これに対して, 図 7 (b)に示すものは最終変形状態にも大きな違いが現れた。特にせん断 スパン比が 3 のものは, 図 8 の実験終了後の最終変形状態に示すよ うに梁全長にわたってウエブにせん断変形が発生しているもので あった。

さらに数值解析対象を増やし，断面積比が異なる場合に，せん断

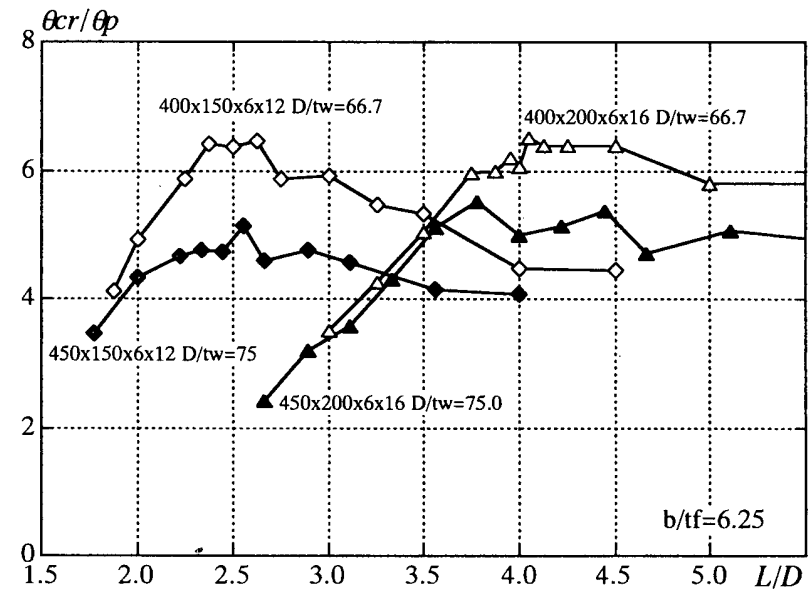

図 9 せん断スパン比と塑性変形能力の関係 
スパン比で梁の最大耐力時の塑性率を整理したものが図 9 である。 明らかにフランジ断面積変化にともなう影響が見られる。全体的な 傾向としては，あるせん断スパン比までは塑性率が大きくなるが， その值より大きなせん断スパンでは，塑性率がほぼ等しくなるか， せん断スパン比の增大にともなって若干塑性率が低下する。フラン ジ幅 $150 \mathrm{~mm}$, フランジ板厚 $12 \mathrm{~mm}$ の断面積比の小さい断面形状のも のは，ウエブ幅厚比によらず塑性率が最大となるせん断スパン比の 值が小さい。これは，断面積比が小さいことでウエブのせん断降伏 がせん断スパン比が小さくなっても起こりにくく，梁に作用する曲 げ応力の割合が高いために，せん断スパン比が小さい範囲において もフランジの局部座屈が支配的な崩壊をするためである。

また同じフランジ幅，フランジ板厚のものに注目した場合，塑性 率が最大となるせん断スパン比よりも小さい範囲では，ウエブ幅厚 比の違いが塑性率に与える影響は小さい。また塑性率が最大となる せん断スパン比よりも大きい範囲では, 塑性率はウエブ幅厚比の違 いによる影響がみられ，ウエブ幅厚比が大きいもので塑性率が小さ くなっている。これらの要因は, 塑性率が最大となるせん断スパン 比を境に支配的な崩壊形が変化するためであると考えられる。つま りせん断スパン比が小さい範囲ではウエブ降伏が支配的な崩壊性状 であることから，ウエブ幅厚比の影響をさほど受けにくい領域であ ク，せん断スパン比が大きい範囲では局部座屈が支配的な崩壊性状 であることから，ウエブ幅厚比に影響を受ける領域である。

このように，断面積比がほぼ等しい場合にはある程度せん断スパ ン比で，その変形性状と塑性率は整理できると考えられる。しかし 断面積比が異なる場合も考慮して評価するには，かならずしも整理 できているとは言い難い。したがって，断面積比とせん断スパン比 の影響の関係を明らかにし，それらを考慮できる因子を抽出する必 要があると考える。

\section{§4. せん断余裕度の定義とせん断曲げを受ける H 形鋼梁の塑性変 形性能}

\section{1 せん断余裕度からみた梁の塑性变形性状}

前章までの考察により，ウエブ幅厚比の大きな梁の塑性変形能力 及び崩壊形式を整理するうえで，ウエブの降伏耐力に注目する必要 があることがわかった。またせん断スパン比及びフランジに対する ウエブの断面積比によっでも梁の塑性変形性状は大きく変化するこ とが確認された。このせん断スパン比，断面積比はウエブの降伏耐 力に大きく関与する要因である。

ところで，本論文で対象としている梁はあくまでも曲げ降伏が先 行する梁であり，せん断曲げ荷重を受けた場合には全塑性モーメン トを確保するものである。したがって，梁ウエブの降伏耐力は，梁 の曲げ耐力との比でとらえた方が梁の塑性変形挙動を考える上で良 い指標となり得るのではないかと考えた。つまり本論文では，梁の 曲げ耐力とウエブのせん断降伏耐力の比を，新たに梁の性状を把握 するための因子として考えることとする。この比は本論文ではせん 断余裕度と称し， ${ }_{w} Q_{p} / Q_{p}$ で表現できるものである。ここで $Q_{p}$ は, 梁端部が全塑性モーメントに達した時に梁に作用しているせん断 力， ${ }_{w} Q_{p}$ は梁のせん断耐力である。例之ば片持梁についてのせん断 余裕度について考えると，以下のような式展開が可能である。

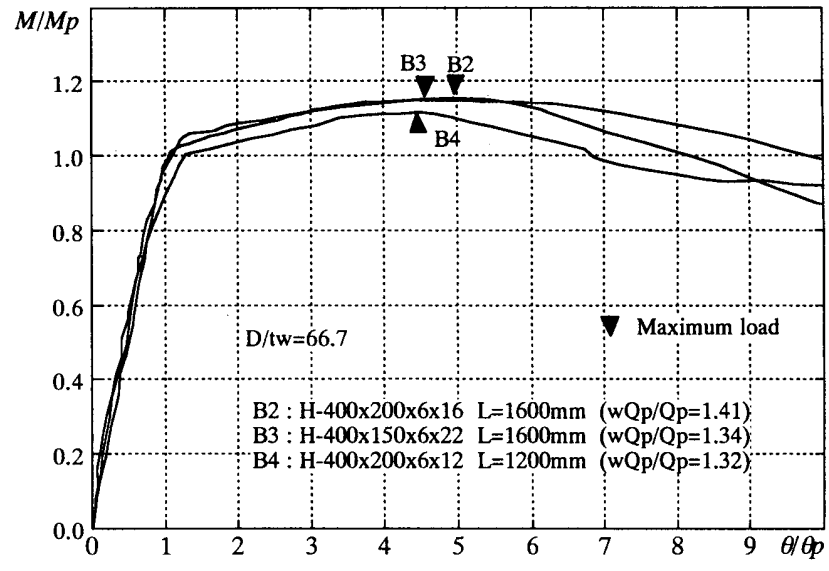

図10 せん断余裕度が等しい場合の荷重変位関係

$$
\begin{aligned}
\frac{{ }_{w} Q_{p}}{Q_{p}} & ={ }_{w} Q_{p} \frac{L}{M_{p}} \\
& =\frac{A_{w} w \sigma_{y}}{\sqrt{3}} \frac{k_{1}}{A_{f f} \sigma_{y} D} L \\
& =k_{2} \frac{A_{w}}{A_{f}} \frac{L}{D}
\end{aligned}
$$

ここで, $M_{p}$ : 梁の全塑性モーメント, $L$ : 片持梁長さ, $D:$ 梁せ い, $A_{w}$ : ウェブ断面積, $A_{f}$ : フランジ断面積, $\sigma_{w}$ : ウェブの降伏応 力度, $\sigma_{f}:$ フランジの降伏応力度, $k_{1}$ : 全塑性モーメントとフランジ のみで考えた全塑性モーメントの比， $k_{2} ： k_{1}$ 及び降伏応力度などを 含む定数である。式(1)より，せん断余裕度は，今までの議論におけ る断面積比とせん断スパン比の影響を全て取り入れた形で評価可能 な因子となっていることが分かる。またせん断余裕度が小さな梁は, せん断崩壊しやすく，せん断余裕度が大きな梁は，曲げ崩壊しやす いものであるといえる。

図10にせん断余裕度がほぼ等しくなるように，断面積比およびせ ん断スパン比を変化させた試験体の荷重変位関係を示す。図中に示 すせん断余裕度 ${ }_{w} Q_{p} / Q_{p}$ は，実測された断面形状及び各板要素の引 張試験から得られた降伏応力度を用いて算出している。この荷重変 位関係を見る限りにおいては，最大耐力時変位量に大きな違いはな く，最大耐力以降の耐力劣化性状に若干の違いがあるものの全体的 な性状としては，ほば等しいと言える。このように梁の断面形状や せん断スパン比に違いがある場合でも，せん断余裕度で梁の塑性変 形性状は概略予測可能であると考えられる。ただし罒 9 でみたよう に構成板要素の幅厚比の影響を同時に考慮する必要がある。以上よ り本研究では, ウェブ幅厚比の大きな梁の塑性変形能力を, せん断 余裕度と構成板要素の幅厚比で整理することができるものとする。

\section{2 せん断曲げを受ける H 形鋼梁の塑性変形能力}

図11は塑性率を本研究で定義するせん断余裕度で整理したもので ある。(a)がウエブ幅厚比75.0のもの，(b)がウエブ幅厚比66.7のもの である。それぞれの眓にはフランジ幅厚比及びフランジ断面積を変 化させて数值解析を行い，その結果を示している。あわせて実験結 果を示しているが, 数値解析結果よりも若干低い值ではあるものの, その傾向は一致している。

ウエブ幅厚比が小さい(b)が(a)に比べ塑性率は大きいものの，全体 的な傾向としては両者ともほぼ同様である。せん断余裕度が梁の塑 


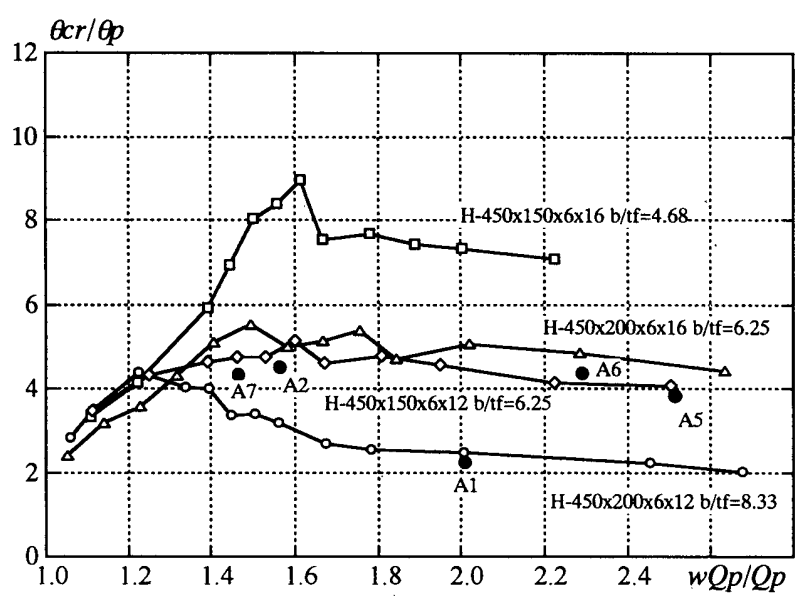

(a) $\mathrm{D} / \mathrm{tw}=75.0$ の場合

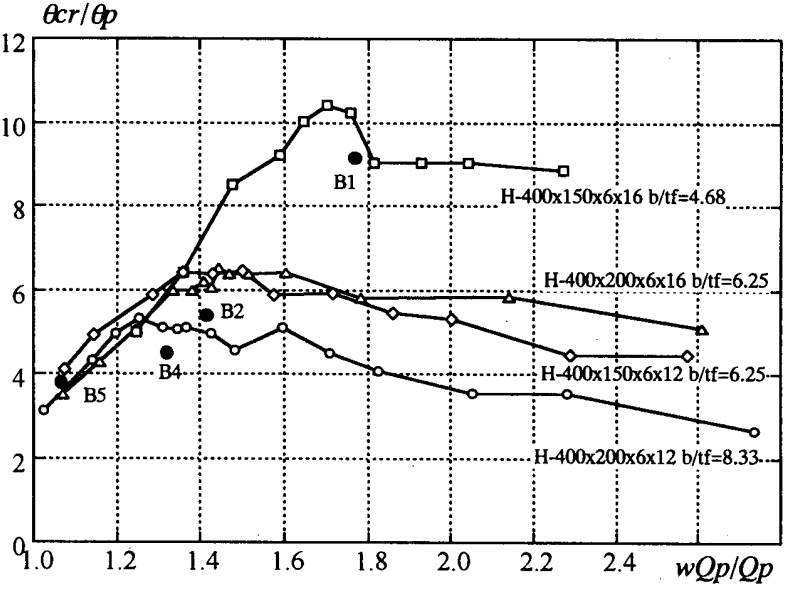

(b) $\mathrm{D} / \mathrm{tw}=66.7$ の場合

图11 せん断余裕度と塑性変形能力の関係

性率に扔よぼす影響を(b)に示すウエブ幅厚比 66.7 の場合で考察す る。せん断余裕度が小さい範囲では，フランジ幅厚比によらずせん 断余裕度と塑性率の関係がほぼ線形関係にある。しかし，フランジ 幅厚比が大きなものほど，せん断余裕度が小さい值でこの線形関係 から離れている。これはフランジ幅厚比が大きいことにより，せん 断余裕度が小さい梁においても，フランジ局部座屈が支配的な崩壊 型へと移行することによるものである。

ここでフランジ幅厚比が4.68と小さなものに着目すれば，塑性率 がほぼ最大となるせん断余裕度のあたりで塑性率の変化が不連続に なっている。これは，崩壊型が混在した形で崩壊していくのではな く，明確に変化していることによるものであると考えられる。つま り塑性変形能力が最大となるあたりで崩壊形式が急激に変化してい ることによる。これに対して，フランジ幅厚比が大きくなると，せ ん断余裕度の変化により塑性率が緩やかに変化している。これは, フランジ局部座屈を伴いながら，ウエブもせん断降伏していくもの であり，これらの両崩壊型が混在した形で梁の崩壊が進んでいくこ とによるものである。

個別に見れば若干の違いはあるものの全体的な傾向としてみるな らば, 塑性率が最大となるせん断余裕度の值は1.6前後であると判断 することが可能である。この 1.6 まではせん断余裕度の減少に伴って 䌐やかに塑性率は上昇するものの1.6以下では急激に低下する。また 梁の崩壊形式も全長にせん断座屈波形が発生するものに近付く。し たがって安定した曲げ崩壊型の崩壊形式を実現するためには, 梁の せん断余裕度を1.6以上にしておくことが必要である。これらの傾向 は, 本研究の範囲のなかではウエブ, フランジの構成板要素幅厚比 によらず同一傾向にあるととらえても差し支えないと考える。

\section{$\S 5$. 結}

本研究は, ウエブ幅厚比の大きな梁を対象として，その最大耐力 決定要因を明らかにすることを目的とした。この中で, ウエブ幅厚 比が大きな梁は, 構成板要素の連成局部座屈で崩壊するもの以外で
は, ウエブの全断面塑性化に伴う風性低下が梁としての耐力を決定 づけていることを明らかにした。このような知見をもとに本研究で は, 梁の塑性変形能力を整理するための新たな指標として, 梁の全 塑性耐力時に梁に作用しているせん断力に対するウエブのせん断耐 力をせん断余裕度と定義し, そのせん断余裕度を用いることで梁の 塑性変形能力及び崩壊形式が予測可能なことを示した。また, 塑性 変形能力がもっとも大きくなるであろうせん断余裕度の值は, 構成 板要素の幅厚比で若干異なる傾向にはあるものの, 本研究で対象と する範囲においては, 1.6前後であるという知見を得た。この值以上 のせん断余裕度を有するような梁では, その崩壊形式がフランジ局 部座屈が支配的なものになり安定した曲げ変形挙動を示す。以上, ウエブ幅厚比の大きな梁の塑性変形挙動をとらえる上で, 構成板要 素の幅厚比とともにせん断余裕度が重要な因子であることを明らか にするとともに，それらを用いて梁の塑性変形能力が整理可能であ ることを示した。

\section{参考文献}

1）鈴木敏郎，五十嵐規矩夫，東 武史，薩川恵一：ウエブ幅厚比の大きな高 張力鋼梁の大変形挙動に関する研究，日本建築学会構造系論文集，No. 504, pp.95 101, 1998.2

2）鈴木敏郎, 五十嵐規矩夫, 東 武史, 薩川恵一：建築構造用高性能 $590 \mathrm{~N} /$ $\mathrm{mm}^{2}$ 鋼材を用いたウエブ幅厚比の大きな梁の塑性変形能力に関する研 究, 日本建築学会構造系論文集, No. 522, pp.113 119, 1999.8

3）大西 浩, 鈴木敏郎, 五十嵐規矩夫, 常木康弘, 石井秀明：せん断応力度 の影響を考慮した $\mathrm{H}$ 形鋼梁の塑性変形能力評価（その1 ウエブ幅厚比 の大きな梁の塑性変形性状), 日本建築学会大会学術梗概集 (東北), pp. $487 \sim 488,2000.9$

4）常木康弘, 鈴木敏郎, 五十嵐規矩夫, 石井秀明：せん断応力度の影響を考 慮した $\mathrm{H}$ 形鎙梁の塑性変形能力評価 (その 2 塑性変形能力評価), 日本 建築学会大会学術梗概集 (東北), pp. $489 \sim 490,2000.9$

5）鈴木敏郎, 小野徹郎, 金箱温春：せん断曲げを受ける鉄骨 H 型断面梁の局 部座屈挙動と塑性変形能力, 日本建築学会論文報告集, No. 260, pp. 91 98, 1977.10

6）日本建築学会：鋼構造設計規準，1973

(2001年 2 月 8 日原稿受理, 2001 年 4 月 17 日採用決定) 